\title{
USING OF TRADITIONAL RECRUITMENT METHODS AND TOOLS AND E-RECRUITMENT BY EMPLOYEES OF BABY BOOMERS GENERATION, GENERATION X, GENERATION Y AND GENERATION Z IN SELECTED HEALTHCARE SERVICE PROVIDERS IN THE CZECH REPUBLIC
}

\author{
[Využívání tradičních metod a nástrojů náboru a E-recruitmentu zaměstnanci \\ generace Baby Boomers, Generace X, Generace Y a Generace Z u vybraných \\ poskytovatelů zdravotních služeb v České republice]
}

\author{
Jiř́i Bejtkovskýn \\ ${ }^{I}$ Univerzita Tomáše Bati ve Zlíně, Fakulta managementu a ekonomiky, Mostni 5139, 76001 Zlín \\ Email: bejtkovsky@utb.cz
}

\begin{abstract}
The paper deals with the human capital management in today's modern information, communication and digital society. The aim of the article was to find out the current level of using of traditional recruitment methods and tools (offline recruitment) in a comparison with E-recruitment (online recruitment). This level of using was investigated and evaluated by employees of the Baby Boomers generation, Generation X, Generation Y, and Generation Z in selected healthcare service providers in the Czech Republic. A questionnaire survey was conducted in the first quarter of 2018 via an anonymous structured questionnaire. One research hypothesis and one research question was formulated. The results of the research revealed that there is a statistically significant dependence between employees of a certain age generation in selected healthcare service providers in the Czech Republic and the active using of traditional recruitment methods and tools in human resource management area.
\end{abstract}

Keywords: baby boomers generation, Czech Republic, e-recruitment, generation X, generation Y, generation $\mathrm{Z}$, healthcare service provider, recruitment.

JEL classification: I10, J24, M12

Doručeno redakci: 8.10.2018; Recenzováno: 22.10.2018; 5.11.2018; Schváleno k publikování: 21.11.2018

\section{Úvod}

Současné podnikatelské prostředí, ale také situace na trhu práce se vyznačují značnými změnami, možnostmi, př́ležitostmi či výzvami nejen pro samotné korporace (firmy, instituce, organizace, podniky, úřady, společnosti), nýbrž i pro jedince. Toto, ač moderní, ale proměnlivé prostředí je tak ovlivňováno různými faktory počínaje faktory ekonomickými, přes faktory sociální, environmentální, demografické, kulturní, politické, legislativní a konče faktory technickými a technologickými. Rozvoj moderních informačních, komunikačních, digitálních a online technologií umožňuje, usnadňuje a zefektivňuje práci v každém odvětví, oboru či činnostech. Oblast zaměřená na řízení lidských zdrojů a lidského kapitálu tomu není výjimkou. V rámci úspory času nebo nákladů mohou být různé klasické a tradiční personální činnosti, metody, procesy či nástroje doplňovány či zcela nahrazovány nejmodernějšími technologiemi. Typickým př́ikladem tak mimo jiné může být například proces plánování, získávání, výběru, přijímání a adaptace lidských zdrojů do jakékoliv dnešní korporace.

Mnohé dnešní korporace (firmy, instituce, organizace, podniky, úřady, společnosti) jsou představovány následujícími skutečnostmi: (1) lze uvažovat o dvou pohlavích zaměstnanců, (2) lze vnímat čtyři typy zaměstnanců dle klasické typologie temperamentu, (3) může vedle sebe pracovat pět generací zaměstnanců, (4) zaměstnanci pracující vedle sebe mohou 
pocházet ze sedmi různých kontinentů. Tyto rozličné skutečnosti je zapotřebí vnímat a pracovat s nimi v oblasti ř́zení lidských zdrojů.

Cílem příspěvku je zjistit aktuální úroveň využívání tradičních metod a nástrojů náboru zaměstnanců (offline recruitment) v komparaci se zaměřením se na E-recruitment (online recruitment). Tato úroveň bude hodnocena zaměstnanci generace Baby Boomers, Generace X, Generace Y a Generace Z u vybraných poskytovatelů zdravotních služeb v České republice. Termín recruitment je $\mathrm{v}$ rámci příspěvku vnímán $\mathrm{v}$ užším pojetí, jako proces aktivního oslovení, přilákání a nalezení vhodného kandidáta na obsazovanou pracovní pozici.

\section{Teoretická východiska související s procesem recruitmentu a současnými generacemi na trhu práce}

Termín recruitment nemá jednotnou definici. Lze toto označení vnímat v širokém i úzkém kontextu. Např́íklad Kumari (2012) definuje recruitment proces jako oslovení, přilákání a nalezení nových kandidátů či potenciálních zaměstnanců na volné pracovní místo nebo pozici a jejich podněcování k uplatnění v organizaci. Dále uvádí, že recruitment proces je proces náboru správných kandidátů na správnou práci. Opatha (2016) tvrdí, že recruitment proces představuje soubor aktivit, které organizace používá $\mathrm{k}$ tomu, aby přilákala uchazeče o zaměstnání, kteří mají potřebné dovednost, znalosti, schopnosti a postoje. Vnímá recruitment jako proces vytváření skupiny kvalifikovaných žadatelů o volné pracovní místo nebo pozici v organizaci. Ofori a Aryeetey (2011) chápou recruitment jako proces náboru, který vede k tvorbě souboru kompetentních jedinců, kteří se ucházejí o zaměstnání v dané organizaci. Zatímco Breaugh (2008) definuje proces náboru lidského kapitálu v jakékoliv korporace, jako soubor aktivit, postupů, metod a činností, které mají prímou vazbu na charakteristiku, typ a počet potenciálních uchazečů, kteří se na volnou pracovní pozici přihlásí, úspěšně splní veškeré předem definované podmínky na konkrétní obsahované pracovní místo a v nejlepším případě také do korporace nastoupí a úspěšně se v ní adaptuje.

\subsection{Offline recruitment aneb tradiční metody a nástroje náboru lidských zdrojů}

Při vzniku potřeby nového pracovního místa či nutnosti př́ijmu zaměstnance na konkrétní pracovní pozici uvažuje management korporace nejdříve o svých stávajících zaměstnancích, tedy o vnitřních zdrojích uchazečů. Někdy se může management snažit přesvědčit své bývalé zaměstnance, aby se $\mathrm{k}$ nim vrátili, nebo se snaží získat doporučení od stávajících zaměstnanců. Pokud nejsou odpovídající uchazeči na vnitřním trhu práce, využívají se vnější zdroje uchazečů, přičemž se potenciální zaměstnanci mimo korporaci oslovují s využitím rozmanitých tradičních metod a nástrojů náboru lidských zdrojů (offline recruitment). Mezi tradiční metody a nástroje - offline recruitment - náboru (nového) personálu do korporace lze zařadit (Armstrong a Taylor 2015; Zottoli a Wanous 2000): (1) personální agentury a agentury zabývající se zprostředkováním práce a poskytující informace a konzultace v oblasti hledání zaměstnání, (2) doporučení od stávajících nebo bývalých zaměstnanců, (3) prŕmé oslovení (head hunting), (4) inzerci v místních novinách, (5) inzerci v odborných časopisech, (6) inzerci v celostátních novinách, (7) spolupráci s úřady práce, (8) vzdělávací instituce různých stupňů či (9) burzy práce a veletrhy pracovních príiležitostí.

\subsection{Online recruitment aneb Internet recruitment, E-recruitment}

Florea a Badea (2013) tvrdí, že prostřednictvím online recruitmentu mohou korporace mimo jiné umístit příspěvek či inzerát o volné pracovní pozici na své webové stránky nebo jej prezentovat na některém internetovém pracovním či kariérovém portálu. E-recruitment umožnuje rychlé oslovení potenciálního segmentu uchazečů o danou pracovní pozici a díky technologiím je stále populárnější, nebot' Internet nevykazuje žádné zeměpisné hranice. Lee 
(2011) říká, že E-recruitment byl přijat jako jeden z úspěšných aplikací elektronického podnikání (E-business) a představuje jeho podvýzkumnou oblast.

Mezi metody a nástroje online recruitmentu - náboru (nového) personálu do korporace lze zařadit (Armstrong a Taylor 2015; Zottoli a Wanous 2000): (1) vlastní webové stránky korporace (firmy, instituce, organizace, podniku, úřadu, společnosti), (2) profesní a klasické platformy sociálních médií a sociálních sítí či (3) pracovní portály a pracovní servery. Acikgoz (2018) v souvislosti s profesními platformami sociálních sítí uvádí, že tyto hrají významnou a dominantní roli při oslovování zejména pasivních uchazečů o konkrétní pracovní pozici vzhledem $\mathrm{k}$ obrovskému počtu jednotlivých profilů.

Offline recruitment je obvykle založen na tištěné formě a dále je charakterizován různými druhy formulářů. Tento typ recruitmentu může být stále účinný ve většině průmyslových odvětví; avšak HR manažeři musejí čelit měnící se situaci na trhu práce a to nejen v souvislosti s procesem transformace a digitalizace, ale také s nedostatkem kvalifikovaného a motivovaného personálu. Naproti tomu online recruitment minimalizuje papírovou práci HR manažerů, zrychluje a automatizuje klíčové aktivity celého recruitment procesu (Lee 2011).

\subsection{Současné generace na trhu práce nejen v kontextu poskytovatelů zdravotních služeb}

Současný trh práce nejen u poskytovatelů zdravotních služeb v České republice je zastoupen čtyřmi generacemi zaměstnanců, a to zaměstnanci: (1) generace Baby Boomers, (2) Generace $\mathrm{X}$, (3) Generace $\mathrm{Y}$ a (4) Generace $\mathrm{Z}$. Představitelé každé z generací vyžadují jiný př́stup, nebot' nevyrůstali ve stejných historických a technologických podmínkách a nelze srovnávat různé společnosti, země či kontinenty. V tomto kontextu lze říci, že v českých a slovenských podmínkách existuje určitá výzkumná mezera v podobě výzkumných studií či příspěvků, které by tuto problematiku zkoumaly a řešily. Pro potřeby tohoto článku proto budou charakterizovány jednotlivé generace dle obecných informací prezentujících danou generaci.

\subsubsection{Generace Baby Boomers}

Generace Baby Boomers představuje pop kulturní označení pro americkou generaci. Na území tehdejšího Československa se zkoumáním generací, nejen na trhu práce, sociologie v dřívějším období nezaobírala (Generacey.cz (C) 2011 - 2012). Generace Baby Boomers tak představuje skupinu obyvatel narozených po druhé světové válce, nejčastěji v rozpětí let 1946 až 1964 (Bolton a kolektiv 2013; Gardiner, Grace a King 2015; Wuest a kolektiv 2008). Tato generace žila v relativně již bezpečné době a v období ekonomické prosperity (Generacey.cz (C) 2011 - 2012). Wiedmer (2015) dále poznamenává v souvislosti s trhem práce nejen v kontextu poskytovatelů zdravotních služeb, že je generace Baby Boomers motivována ziskem, prestiží, pracovním postavením, ale zároveň vykazuje silnou pracovní morálku i etiku a ostýchají se vzdát odpovědnosti, kterou v průběhu let získali. Lidé generace Baby Boomers jsou optimističtí, nebáli a nebojí se utrácet, a to zejména za produkty či služby, které jim určitým způsobem usnadňují život. Představitelé generace Baby Boomers nejsou v současné době již bohužel všichni ekonomicky aktivní (Generacey.cz (C) 2011 2012). Cochran, Stoll a Kinsiger (2006) v této souvislosti dále doplňují skutečnost, že představitelé generace Baby Boomers jsou obecně mnohem zdravější než generace, která jim předchází a hledají živé a zábavné zážitky při odchodu do důchodu.

\subsubsection{Generace X (Gen Xers)}

Generací $\mathrm{X}$ jsou označováni ti, kteří vyrostli v západní Evropě nebo ve Spojených státech amerických. Na území bývalého Československa je tato generace nazývána termínem Husákovy děti (Generacey.cz (C) 2011 - 2012). Pro tuto generaci osob je charakteristický 
skeptický a pesimistický pohled na svět, což dokládá stav světové ekonomiky v sedmdesátých letech, Studená válka či zvýšená rozvodovost (Generacey.cz (C) 2011 - 2012; Heaney 2007). Generace $\mathrm{X}$ nejen v kontextu poskytovatelů zdravotních služeb představuje skupinu obyvatel narozených v rozpětí let 1965 až 1980 (Bolton a kolektiv 2013; Fry (C) 2016; Gardiner, Grace a King 2015; Wuest a kolektiv 2008). Z hlediska trhu práce je tato generace typická menší mírou loajality vůči zaměstnavateli a nemají rádi formality (Rowe 2008). Becton, Walker a Jones-Farmer (2014) dále doplňují, že zaměstnanci Generace X jsou méně ochotni pracovat přesčas než představitelé generace Baby Boomers, když jsou o to nadřízenými zaměstnanci požádáni. V komparaci s generací Baby Boomers dále vykazují představitelé Generace X většího podnikatelského ducha a odvahu (Howe a Strauss 2007).

\subsubsection{Generace Y (Mileniálové)}

Jedná se o první generaci obyvatel, která vyrostla v obklopení moderních informačních, komunikačních a digitálních technologií. Generace Y je také vnímána jako první globální generace, kdy prostřednictvím Internetu dochází k propojení lidí na celém světě. Lidé z Generace Y jsou si svými vlastnostmi velmi podobní, i když pocházejí z různých částí světa. Na území bývalého Československa a dnešní České republiky se uklidnila světová politika i ekonomika. Sametová revoluce přinesla určitou míru svobody a demokracii. Ekonomika zaživala v devadesátých letech rozmach (Generacey.cz (C) 2011 - 2012). Klapilová Krbová (2016) uvádí, že zaměstnanci Generace Y využívají Internet a platformy sociálních médií ke komunikaci a mají zájem o nové technologie. Když jim to charakter pracovní pozice dovolí, aktivně využívají online nástroje, ve kterých spatřují výhody. Generace Y představuje skupinu obyvatel narozených v rozpětí let 1981 až 1997 (Bolton a kolektiv 2013; Wuest a kolektiv 2008; Yan 2003). Z hlediska trhu práce je tato generace vnímána jako optimistická, věŕící v lepší zítřky a preferující určitou míru pracovní svobody (Cennamo a Gardner 2008; Generacey.cz (C) 2011 - 2012). Becton, Walker a Jones-Farmer (2014) dále doplňují, že zaměstnanci Generace $\mathrm{Y}$ jsou méně ochotni pracovat přesčas než představitelé generace Baby Boomers, když jsou o to nadřízenými zaměstnanci požádáni.

\subsubsection{Generace $Z$ (internetová generace)}

Generace Z je také označována jako tichá generace, kvůli technologiím, které jsou dnes aktuální, a ty ji dávají jméno tiché - iGenerace, generace tiché, př́ští generace (Cook 2015; Gouws a Tarp 2016). Bassiouni a Hackley (2014); Bolton a kolektiv (2013) charakterizují Generaci $\mathrm{Z}$ nejen v kontextu poskytovatelů zdravotních služeb jako mladé dospělé, kteří se narodili v rozpětí let 1998 až 2012. Základním rysem této generace osob je neustálá potřeba být online, skypovat, chatovat či checkovat videa na různých platformách sociálních médií. Online komunita a komunikace je pro tuto generaci velmi důležitá. Většinu věcí tyto osoby dělají jinak než ostatní generace. $Z$ hlediska trhu práce projevují zaměstnanci této generace své názory, ale řídí se názorem svých vrstevníků (Generacey.cz (C 2011 - 2012). V souvislosti s online prostředím Issa a Isaias (2016) tvrdí, že osoby Generace $\mathrm{Z}$ jsou hlavními uživateli Internetu a využívají ho pro plnění pracovních či studijních potřeb (odpovídání na e-maily) anebo pro socializaci (platformy sociálních sítí, například Facebook, Instagram, Twitter, YouTube, LinkedIn a další). Becton, Walker a Jones-Farmer (2014) dále doplňují, že zaměstnanci Generace $Z$ jsou méně ochotni pracovat přesčas než představitelé generace Baby Boomers, když jsou o to nadř́zenými zaměstnanci požádáni. West (2014) vnímá zaměstnance Generace $Z$ nejen v kontextu poskytovatelů zdravotních služeb jako (1) velmi dobře adaptabilní na technologie, (2) environmentálně smýšlející a (3) schopné rychle a efektivně pracovat s různými druhy informací. 
Následující tabulka (Tabulka 1) shrnuje vlastnosti jednotlivých generací osob v kontextu trhu práce.

Tabulka 1: Vlastnosti jednotlivých generací osob v kontextu trhu práce

\begin{tabular}{|c|c|}
\hline Sledovaná generace zaměstnanců & Vlastnosti osob dané generace \\
\hline Generace Baby Boomers & Silná pracovní morálka, etické jednání, zodpovědnost \\
\hline Generace X (Gen Xers) & Menší míra loajality a ochoty k práci přesčas, malý sklon k formalitám \\
\hline Generace Y (Mileniálové) & Preference určité míry pracovní svobody, menší ochota k práci přesčas \\
\hline Generace Z (internetová generace) & Menší ochota k práci přesčas, dobrá a rychlá adaptibilita na technologie \\
\hline
\end{tabular}

Zdroj: Vlastní zpracování dle Becton, Walker a Jones-Farmer (2014); Cennamo a Gardner (2008); Generacey.cz (C) 2011 - 2012); Rowe (2008); West (2014); Wiedmer (2015)

\section{Cíl, metodika a data}

Cílem příspěvku je prostřednictvím kvantitativního marketingového výzkumu realizovaného dotazníkovým šetřením zjistit současnou úroveň využívání tradičních metod a nástrojů náboru zaměstnanců (offline recruitment) v komparaci se zaměřením se na E-recruitment (online recruitment). Současná úroveň využívaní recruitmentu je zkoumána u vzorku respondentů $\mathrm{Z}$ řad zaměstnanců generace Baby Boomers, Generace X, Generace Y a Generace Z, kteří jsou zaměstnáni u vybraných poskytovatelů zdravotních služeb v České republice.

Základní soubor představoval celkem 298 respondentů, kteří splňovali stanovené segmentační charakteristiky, a kteří byli zaměstnáni u vybraných poskytovatelů zdravotních služeb v České republice. Vybraní poskytovatelé zdravotních služeb byli do výzkumu vybráni na základě již dřive realizované výzkumné spolupráce.

Teoretická východiska související s náborem lidských zdrojů a současnými generacemi na trhu práce vycházejí ze studia a analýzy sekundárních infomačních zdrojů. Zejména se tak jedná o vědecké časopisy, které jsou indexovány v databázi Scopus a také v databázi Web of Science či další sekundární zdroje.

Primární zdroje informací jsou získány kvantitativním výzkumem, přičemž některé výsledky $\mathrm{z}$ tohoto šetření jsou prezentovány v tomto příspěvku. Dotazníkové šetření bylo uskutečněno v prvním čtvrtletí roku 2018 prostřednictvím anonymního strukturovaného dotazníku, který měl papírovou podobu. Cílem dotazníku bylo mimo jiné zjistit, zda respondenti dávají přednost tradičním metodám náboru nebo se více orientují na metody a nástroje online náboru. Respondenti byli zaměstnanci, kteř́ jsou zaměstnáni u vybraných poskytovatelů zdravotních služeb v České republice a tito respondenti byli dále rozděleni podle dvou segmentačních charakteristik. První segmentační kritérium bylo zaměřeno na charakteristiku určující jednotlivé generace na trhu práce, a to zaměstnance generace (1) Baby Boomers, (2) Generace X, (3) Generace Y, (4) Generace Z. Druhé segmentační kritérium sledovalo délku pracovního poměru každého ze zaměstnanců u vybraných poskytovatelů zdravotních služeb v České republice. Jelikož se jednalo o nově přijaté zaměstnance do pracovního poměru, byla tato otázka sledována $\mathrm{v}$ časovém intervalu od nuly do maximálně šesti měsíců. Tato vstupní proměnná byla následně relevantní pro zodpovězení stanovené výzkumné otázky, proto byla definována v tomto znění. Samozřejmostí je, že využívaný dotazník dodržoval a respektoval veškeré aspekty etického charakteru. V rámci dotazníkového šetření byly využity otázky 
otevřené, polootevřené, ale i uzavřené, které mapovaly zjištění související s výzkumným problémem. Pro kvalitní a relevantní zjištění výzkumných dat a informací byl uskutečněn v prosinci 2017 pretest dotazníku. Tohoto předběžného testování dotazníku se zúčastnilo pět respondentů. Díky pretestu se podařila selekce otázek, které nebyly jasně formulovány a dotazník tak byl připraven pro svoji distribuci. S počtem 298 respondentů se dále pracovalo v rámci verifikace výzkumné hypotézy a zodpovězení výzkumné otázky. Testování výzkumné hypotézy bylo provedeno prostřednictvím metody Pearsonova chí-kvadrát testu. Tento test je založen na měření daných závislostí, jehož prostřednictvím se zjistí, zda existuje závislost mezi statistickými znaky. Pokud je hodnota P nižší než zvolená úroveň významnosti (obvykle 0.05 , tedy $5 \%$ ), je definovaná nulová hypotéza zamítnuta. V rámci vyhodnocení získaných dat byly použity typické statistické programy, a to IBM SPSS Statistics 23 a také Microsoft Excel 2013.

\section{Výsledky a diskuze}

Na základě teoretických východisek, která jsou zaměřena na nábor lidských zdrojů a současné generace na trhu práce byla formulována jedna výzkumná hypotéza (H1) a stanovena jedna výzkumná otázka (VO1).

H1: Existuje statisticky významná závislost mezi zaměstnanci z určité věkové generace u vybraných poskytovatelů zdravotních služeb v České republice a aktivním využíváním tradičních metod a nástrojů náboru lidských zdrojů.

VO1: Jaký zdroj informací prezentující volnou pracovní pozici u vybraných poskytovatelů zdravotních služeb v České republice byl oslovenými zaměstnanci z určité věkové generace nejvíce využit?

Výzkumná hypotéza byla verifikována prostřednictvím Pearsonova chí-kvadrát testu za využití statistického programu IBM SPSS Statistics 23 a také pomocí programu Microsoft Excel 2013. Struktura respondentů z řad zaměstnanců generace Baby Boomers, Generace X, Generace $\mathrm{Y}$ a Generace $\mathrm{Z}$ u vybraných poskytovatelů zdravotních služeb v České republice je prezentována $\mathrm{v}$ níže uvedené tabulce (Tabulka 2).

Tabulka 2: Struktura respondentů z řad zaměstnanců generace Baby Boomers, Generace $X$, Generace $\mathrm{Y}$ a Generace $\mathrm{Z}$ u vybraných poskytovatelů zdravotních služeb

\begin{tabular}{|c|c|c|c|}
\hline $\begin{array}{c}\text { Sledovaná } \\
\text { charakteristi } \\
\text { ka }\end{array}$ & Sledovaná kategorie (proměnná & $\begin{array}{l}\text { Absolutní } \\
\text { četnost (n) }\end{array}$ & $\begin{array}{l}\text { Relativní } \\
\text { četnost (\%) }\end{array}$ \\
\hline \multirow{3}{*}{$\begin{array}{l}\text { Pohlaví } \\
\text { respondentů }\end{array}$} & Ženy & 184 & 61.74 \\
\hline & Muži & 114 & 38.26 \\
\hline & Celkem & 298 & 100.00 \\
\hline \multirow{5}{*}{$\begin{array}{l}\text { Generace } \\
\text { zaměstnanců }\end{array}$} & Baby Boomers generace $(1946-1964)$ & 11 & 3.69 \\
\hline & Generace X $(1965-1980)$ & 146 & 48.99 \\
\hline & Generace Y $(1981$ - 1994) & 118 & 39.60 \\
\hline & Generace Z (1995+) & 23 & 7.72 \\
\hline & Celkem & 298 & 100.00 \\
\hline \multirow{4}{*}{$\begin{array}{l}\text { Pracovníci } \\
\text { ve } \\
\text { zdravotnictví } \\
\text { podle } \\
\text { kategorií }\end{array}$} & Lékaři a zubní lékaři & 49 & 16.44 \\
\hline & Farmaceuti & 13 & 4.36 \\
\hline & Všeobecné sestry a porodní asistentky & 61 & 20.48 \\
\hline & Ostatní zdravotničtí pracovníci nelékaři s odbornou způsobilostí & 27 & 9.06 \\
\hline
\end{tabular}




\begin{tabular}{|c|c|r|r|}
\hline \multirow{4}{*}{} & $\begin{array}{c}\text { Zdravotničtí pracovníci nelékaři s odbornou a specializovanou } \\
\text { způsobilostí }\end{array}$ & 14 & 4.70 \\
\cline { 2 - 4 } & Zdravotničtí pracovníci nelékaři pracující pod odborným dohledem & 46 & 15.44 \\
\cline { 2 - 4 } & Jiní odborní pracovnici nelékaři s odbornou způsobilostí, dentisté & 15 & 5.03 \\
\cline { 2 - 4 } & Pedagogičtí pracovníci & 0 & 0.00 \\
\cline { 2 - 4 } & Technicko-hospodářští pracovníci & 31 & 10.40 \\
\cline { 2 - 4 } & Dělníci a provozní pracovníci & 42 & 14.09 \\
\cline { 2 - 4 } & Celkem & $\mathbf{2 9 8}$ & $\mathbf{1 0 0 . 0 0}$ \\
\hline \multirow{3}{*}{$\begin{array}{c}\text { Délka } \\
\text { pracovního } \\
\text { poměru } \\
\text { zaměstnance }\end{array}$} & $0-1$ měsíc & 87 & 29.19 \\
\cline { 2 - 4 } & $2-4$ měsíce & 109 & 36.58 \\
\cline { 2 - 4 } & $5-6$ měsíců & $\mathbf{2 9 8}$ & 34.23 \\
\hline
\end{tabular}

Zdroj: Vlastní zpracování

Výzkumná hypotéza (H1): Existuje statisticky významná závislost mezi zaměstnanci z určité věkové generace u vybraných poskytovatelů zdravotních služeb v České republice a aktivním využíváním tradičních metod a nástrojů náboru lidských zdrojů.

H0: Neexistuje statisticky významná závislost mezi zaměstnanci z určité věkové generace u vybraných poskytovatelů zdravotních služeb v České republice a aktivním využíváním tradičních metod a nástrojů náboru lidských zdrojů.

Údaje charakterizující výzkumnou hypotézu (H1) jsou uvedeny v níže prezentované tabulce (Tabulka 3).

Tabulka 3: Verifikace výzkumné hypotézy (H1) pomocí Pearsonova chí-kvadrát testu

\begin{tabular}{|c|c|c|c|}
\hline $\begin{array}{c}\text { H1: Existuje statisticky významná závislost mezi zaměstnanci } \mathbf{z} \text { určité věkové generace u vybraných } \\
\text { poskytovatelů zdravotních služeb v České republice a aktivním využiváním tradičních metod a } \\
\text { nástrojů náboru lidských zdrojů. }\end{array}$ \\
\hline statistická metoda & hodnota chí-kvadrátu & stupeň volnosti & hodnota $\mathbf{P}$ \\
\hline Pearsonův chí-kvadrát test & 46.743 & 3 & .000 \\
\hline hodnota koeficientu Cramerova $\mathbf{V}$ & .238 & $\begin{array}{c}\text { statistická } \\
\text { interpretace }\end{array}$ & $\begin{array}{c}\text { vztah je slabý } \\
\text { (malý) }\end{array}$ \\
\hline
\end{tabular}

Zdroj: Vlastní zpracování v programu SPSS Statistics 23 (2018)

V rámci zvažování závislosti mezi zaměstnanci $\mathrm{z}$ určité věkové generace u vybraných poskytovatelů zdravotních služeb v České republice a aktivním využíváním tradičních metod a nástrojů náboru lidských zdrojů byla zjištěna hodnota $\mathrm{P}$ nižší než standardně využívaná úroveň významnosti (obvykle 0.050). Výsledkem verifikace definované výzkumné hypotézy H1 je zjištění, že stanovená nulová hypotéza o nezávislosti (H0) byla odmítnuta na hladině významnosti $5 \%$. Lze tedy říci, že výzkumná hypotéza $\mathrm{H} 1$ nebyla zamítnuta. Prostřednictvím koeficientu Cramerova V lze konstatovat, že je vztah mezi definovanými a sledovanými proměnnými slabý či malý, což dokazuje i jeho hodnota (0.238).

Výzkumná hypotéza (H1) - existuje statisticky významná závislost mezi zaměstnanci z určité věkové generace u vybraných poskytovatelů zdravotních služeb v České republice a aktivním využíváním tradičních metod a nástrojů náboru lidských zdrojů - byla potvrzena. Dále lze konstatovat, že zaměstnanci Generace $\mathrm{Y}$ a Generace $\mathrm{Z}$ jsou více nakloněni k moderním metodám a nástrojům náboru lidských zdrojů, což je pochopitelné v souvislosti s online 
prostředím, ve kterém vyrůstali oproti zbylým zkoumaným generacím. Toto zjištění také podporuje stanovená a výše prezentovaná teoretická východiska.

VO1: Jaký zdroj informací prezentující volnou pracovní pozici u vybraných poskytovatelů zdravotních služeb v České republice byl oslovenými zaměstnanci z určité věkové generace nejvíce využit?

Anonymní strukturované dotazníkové šetření mimo jiné obsahovalo výčtovou otázku, v rámci které měli oslovení respondenti uvést zdroj informací, ze kterého se dověděli o volné obsazované pracovní pozici u vybraného poskytovatele zdravotních služeb v České republice. Zaměstnanci $\mathrm{z}$ určité věkové generace si mohli zvolit následující alternativy možných odpovědí: (1) doporučení od přátel nebo kamarádů, (2) doporučení od kolegů nebo známých, (3) odborné či klasické tiskoviny či leták, (4) personální, headhuntingová, poradenská či zprostředkovatelská agentura, (5) úřad práce, (6) vzdělávací instituce různých stupňů, (7) odborné konference, (8) burza práce či veletrh pracovních příležitostí, (9) rádio, (10) webové stránky daného poskytovatele zdravotních služeb, (11) klasické internetové pracovní portály (jako např́klad jobs.cz, prace.cz a tak podobně) a/nebo e-mail, (12) odborné internetové portály, (13) platformy sociálních médií (jako např́klad LinkedIn, Facebook, Instagram, YouTube, Twitter a tak dále).

Tabulka (Tabulka 4) prezentuje zdroje informací prezentující volnou pracovní pozici u vybraných poskytovatelů zdravotních služeb v České republice, které byly nejvíce využity oslovenými zaměstnanci z určité věkové generace.

Tabulka 4: Zdroje informací prezentující volnou pracovní pozici u vybraných poskytovatelů zdravotních služeb v České republice podle četnosti využití oslovených zaměstnanců z určité věkové kategorie

\begin{tabular}{|c|c|c|}
\hline $\begin{array}{c}\text { Generace zaměstnanců } \\
\text { na trhu práce }\end{array}$ & Zdroj informací & $\begin{array}{c}\text { Absolutní } \\
\text { četnost (n) }\end{array}$ \\
\hline $\begin{array}{c}\text { Baby Boomers generace } \\
(1946-1964)\end{array}$ & doporučení od kolegů nebo známých & 6 \\
\hline $\begin{array}{c}\text { Generace X } \\
(1965-1980)\end{array}$ & personální, headhuntingová, poradenská či zprostředkovatelská \\
\hline $\begin{array}{c}\text { Generace Y Yentura } \\
(1981-1994)\end{array}$ & klasické internetové pracovní portály & 58 \\
\hline $\begin{array}{c}\text { Generace Z } \\
(1995+)\end{array}$ & klasické internetové pracovní portály & 73 \\
\hline
\end{tabular}

Zdroj: Vlastní zpracování

Na základě výše uvedené tabulky (Tabulka 3) lze stanovit zjištění mapující zdroje informací prezentující volnou pracovní pozici u vybraných poskytovatelů zdravotních služeb v České republice. Zaměstnanci Baby Boomers generace se o volné pracovní pozici dověděli prostřrednictvím doporučení od svých kolegů či známých. Celkově byla tato alternativa možnosti zastoupena šestkrát. Zaměstnanci Generace $X$ na volnou pracovní pozici u svého poskytovatele zdravotních služeb nastoupili díky personální, headhuntingové, poradenské či zprostředkovatelské agentuře. Mladší generace zaměstnanců (Generace Y a Generace Z) u vybraných poskytovatelů zdravotních služeb své současné pracovní místo objevila díky klasickým internetovým pracovním portálům využívaným na území České republiky. 
Vzhledem k tomu, že nebyly nalezeny žádné identické či podobné výzkumné studie, mohlo by být př́nosné zkoumat i nadále tuto výzkumnou oblast. Následná diskuse obsahuje alespoň obecné výzkumné studie, které se v určitém kontextu tímto výzkumným tématem zabývaly.

Na základě výzkumných studií realizovaných Caers a Castelyns (2011) lze říci, že kromě tradičních metod a nástrojů náboru lidských zdrojů do korporace začínají být mnohem aktivněji využívány také online metody a nástroje. Celkem $44.3 \%$ respondentů uvedlo, že kromě tradičních metod náboru využívají také LinkedIn. Dále $57.8 \%$ oslovených respondentů tvrdí, že platformy sociálních médií (zejména pak LinkedIn a Facebook) jsou vhodné pro informování o dané korporaci či nabízených volných pracovních místech. Přičemž se zde $\mathrm{v}$ rámci těchto výzkumů jednoznačně shodují vtom, že LinkedIn i Facebook nejsou vhodnými nástroji pro interní recruitment lidských zdrojů. Skeels a Grudin (2009) prezentují závěry svých výzkumů, kde uvádějí, že platformy sociálních médií, zejména pak Facebook a LinkedIn, patř́i mezi nejoblíbenější mezi mladými uživateli, zejména pak u Generace Y a Generace Z. V této souvislosti dále uvádějí, že celkem $52.0 \%$ oslovených respondentů aktivně využívá k profesním a pracovním účelům LinkedIn, 49.0\% Facebook a $6.0 \%$ respondentů využívá nejen k náborovým účelům Twitter. Dále prezentují zjištění, že s nárůstem biologického věku respondentů klesá využívání platforem sociálních médií. Eveleth, Stone a Baker-Eveleth (2018) díky svým výzkumným studiím dospěli k závěrům, že kvalitní a zajímavý obsah webových stránek nejen poskytovatele zdravotních služeb, ale všech korporací, znalost korporace potenciálním novým zaměstnancem a platformy sociálních médií velmi pozitivně ovlivňují vnímání nejen poskytovatele zdravotních služeb, ale všech korporací (firem, institucí, organizací, podniků, úřadů, společností).

Pro posílení tradičních metod a nástrojů náboru lidských zdrojů do korporace uvádějí Fajčíková, Urbancová a Kučírková (2018) závěry svých výzkumů, kde přicházejí se zjištěním, že snahou každé korporace je mít kvalifikovaný personál na všech úrovních. Kvalifikovaný personál lze tak získat nejen rozvojem svých současných lidských zdrojů, ale lze získat také prostřednictvím tradičních metod a nástrojů recruitmentu skrze vnější trh práce.

Issa a Isaias (2016) se ve svých výzkumech zabývali Generací Y a Generací Z nejen $\mathrm{z}$ hlediska trhu práce. Jejich výsledky ukázaly, že respondenti těchto generací mnohem aktivně využívají platformy sociálních médií než představitelé generace Baby Boomers a Generace X a zároveň respondenti uvedli, že jim sociální média pomáhají zvyšovat jejich povědomí o lokální i globální situaci. Nejen poskytovatelé zdravotních služeb v České republice, ale i ostatní korporace (firmy, instituce, organizace, podniky, úřady, společnosti) využívají, podle výzkumů, které realizovali Urbancová, Stachová a Stacho (2015), k vlastní sebeprezentaci a upoutání pozornosti nového, potenciálního zaměstnance: (1) své webové stránky (43.7\%), (2) pozitivní a kladné reference o korporaci $(38.7 \%)$ a reklamy $(32.4 \%)$. Toto výzkumné zjištění podporuje tvrzení, že v současné době využívají korporace kombinaci tradičních metod a nástrojů náboru a E-recruitmentu pro získání (nového) zaměstnance na obsazované pracovní místo či pracovní pozici v kontextu generací zaměstnanců na trhu práce, tedy Baby Boomers generace, Generace X, Generace Y a Generace Z. V této souvislosti dále Herbell a Zauszniewski (2018) doplňují, že online metody a nástroje jsou a budou více aplikovány zejména proto, že jsou: (1) přitažlivé, (2) poměrně levné, (3) jednoduché, kreativní a efektivní a (4) mohou oslovit rozmanité množství populace.

\section{Závěr}

Výzkumný příspěvek se zabývá oblastí řízení lidského kapitálu v dnešní moderní informační, komunikační a digitální společnosti. V úvodní části jsou definovány tradiční metody 
a nástroje náboru lidských zdrojů do korporace (firmy, instituce, organizace, podniku, úřadu, společnosti) a následně je věnována pozornost také oblasti E-recruitmentu. Novost a hodnota daného článku spočívá $v$ těchto rovinách: (1) komparace offline a online metod a nástrojů recruitmentu $\mathrm{v}$ kontextu vybraných poskytovatelů zdravotních služeb v České republice, kde byl stanoven výzkumný vzorek segmentovaný dle biologického věku respondentů, (2) zjištění, jaké druhy komunikačních kanálů zaměstnanci různých věkových generací využívají v rámci procesu recruitmentu, což následně může managementu vybraného poskytovatele zdravotních služeb v České republice stanovit významnost či efektivitu daného komunikačního kanálu, kde byl inzerát o volné pracovní pozici umístěn. Na základě zpracované literární rešerše byl výzkum dále postaven na identifikování výzkumného souboru pomocí tak zvaných generací osob na trhu práce. Pracovalo se tedy s označením zaměstnanců generace Baby Boomers, Generace X, Generace Y a Generace Z, kteří jsou v současné době zaměstnáni u vybraných poskytovatelů zdravotních služeb v České republice. Cílem článku tak bylo zjistit současnou úroveň využivání tradičních metod a nástrojů náboru zaměstnanců (offline recruitment) v komparaci se zaměřením se na E-recruitment (online recruitment). Tento cíl byl mimo jiné naplněn formulováním výzkumné hypotézy a výzkumné otázky. Verifikací výzkumné hypotézy bylo zjištěno, že existuje statisticky významná závislost mezi zaměstnanci z určité věkové generace u vybraných poskytovatelů zdravotních služeb v České republice a aktivním využíváním tradičních metod a nástrojů náboru lidských zdrojů. Tento vztah lze charakterizovat jako slabý. Dále lze říci, že respondenti realizovaného výzkumu, kteří byli zaměstnanci Generace $Y$ a Generace $Z$ vykazovali větší otevřenost a aktivitu $\mathrm{k}$ moderním metodám a nástrojům náboru lidských zdrojů, než tomu bylo u zaměstnanců generace Baby Boomers a Generace X. Tuto skutečnost také podpořila stanovená výzkumná otázka. Výzkumný př́spěvek má však určitá omezení: (1) výzkumný vzorek respondentů nebyl př́liš rozsáhlý, (2) respondenti byli zaměstnanci vybraných poskytovatelů zdravotních služeb a ne všech poskytovatelů na základě např́klad geografické segmentace, (3) respondenti byli pouze nově přijatí zaměstnanci do pracovního poměru, (4) výzkum byl realizován pouze na území České republiky, (5) některé generace zaměstnancủ mohou být obavy či předsudky vůči využívání moderních metod a nástrojů online recruitmentu. I přes tyto limity výzkumný př́spěvek přináší nové a zajímavé informace $\mathrm{v}$ oblasti offline a online recruitmentu a dále nabízí rozmanité okruhy a otázky pro další výzkum. Jednou z otázek je zjištění, zda by se změnily informační komunikační kanály u zaměstnanců různých věkových generací na trhu práce při hledání nového pracovního místa. Další otázka by mohla např́íklad souviset s komparací vybraných poskytovatelů zdravotních služeb v České republice a dalších korporací v jiné odvětvové klasifikaci v kontextu různých věkových generací na trhu práce. Jednou z posledních otázek může být zjištění, do jaké míry jsou efektivní a účinné platformy sociálních médií (zejména pak LinkedIn a Facebook) v kontextu interního recruitmentu lidských zdrojů do korporace (firmy, instituce, organizace, podniku, úřadu, společnosti).

\section{Literatura}

[1] ACIKGOZ, Y., 2018. Employee recruitment and job search: Towards a multi-level integration. Human Resource Management Review, Available online 26 February 2018. DOI: https://doi.org/10.1016/j.hrmr.2018.02.009.

[2] ARMSTRONG, M. a S. TAYLOR, 2015. Řizení lidských zdrojů: moderní pojetí a postupy. 13. vyd. Praha: Grada Publishing, 920 s. ISBN 978-80-247-5258-7.

[3] BASSIOUNI, D. H. and C. HACKLEY, 2014. 'Generation Z' children's adaptation to digital consumer culture: A critical literature review. Journal of Customer Behaviour, 13(02), 113-133. DOI: 10.1362/147539214X14024779483591. 
[4] BECTON, J. B., H. J. WALKER and A. JONES-FARMER, 2014. Generational differences in workplace behavior. Journal of Applied Social Psychology, 44(03), 175189.

[5] BOLTON, R. N., A. PARASURAMAN, A. HOEFNAGELS, N. MICHELS, S. KABADAYI, T. GRUBER, Y. K. LOUREIRO and D. SOLNET, 2013. Understanding Generation Y and their use of social media: a review and research agenda. Journal of Service Management, 24(03), 245-267.

[6] BREAUGH, J. A., 2008. Employee recruitment: Current knowledge and important areas for future research. Human Resource Management Review, 18(03), 103-118. DOI: https://dx.doi.org/10.1016/j.hrmr.2008.07.003.

[7] CAERS, R. and V. CASTELYNS, 2011. LinkedIn and Facebook in Belgium: The Influences and Biases of Social Network Sites in Recruitment and Selection Procedures. Social Science Computer Review, 29(04), 437-448. DOI: 10.1177/0894439310386567.

[8] CENNAMO, L. and D. GARDNER, 2008. Generational differences in work values, outcomes and person-organisation values fit. Journal of Managerial Psychology, 23(08), 891-906.

[9] COCHRAN, L., S. STOLL and M. KINSIGER, 2006. Looking through a new lens. Parks \& Recreation, 41(01), 44-49.

[10] COOK, V. S., 2015. Engaging generation z students. Sites.google.com [online]. (C) 2015 [vid. 28. Srpna 2018]. Dostupné https://sites.google.com/a/uis.edu/colrs_cook/home/engaging-generation-z-students.

[11] EVELETH, D., R. STONE and L. BAKER-EVELETH, 2018. The Influence of Recruitment Websites on Job-Seeker Perceptions of Organization and Job Fit. International Journal of Technology and Human Interaction, 14(04), 01-22. DOI: 10.4018/IJTHI.2018100101.

[12] FAJČÍKOVÁ A., H. URBANCOVÁ and L. KUČÍRKOVÁ, 2018. Decisive Factors of Talent Management Implementation in Czech Organisations. Journal on Efficiency and Responsibility in Education and Science, 11(01), 09-15, DOI: 10.7160/eriesj.2018.110102.

[13] FLOREA, N. V. and M. BADEA, 2013. Acceptance of new Technologies in HR: ERecruitment in Organizations. In: Proceedings of the 4th International Conference on Information Systems Management and Evaluation (ICIME 2013). Vietnam: ICIME, s. 344-352. ISBN 978-1-909507-18-0.

[14] FRY, R., 2016. Millennials overtake baby boomers as America's largest generation. [online]. (C) 2016 [vid. 28. srpna 2018]. Dostupné z: https://www.pewresearch.org/facttank/2016/04/25/millennials-overtake-baby-boomers/.

[15] GARDINER, S., D. GRACE and C. KING, 2015. Is the Australian domestic holiday a thing of the past? Understanding baby boomer, Generation $\mathrm{X}$ and Generation $\mathrm{Y}$ perceptions and attitude to domestic and international holidays. Journal of Vacation Marketing, 21(04), 336-350.

[16] GOUWS, R. H. and S. TARP, 2016. Information overload and data overload in lexicography. International Journal of Lexicography, 29(03), 01-27.

[17] HEANEY, J., 2007. Generations X and Y's internet banking usage. Journal of Financial Services Marketing, 11(03), 196-210. 
[18] HERBELL, K. and J. A. ZAUSZNIEWSKI, 2018. Facebook or Twitter?: Effective recruitment strategies for family caregivers. Applied Nursing Research, 41(01), 01-14. DOI: https://doi.org/10.1016/j.apnr.2018.02.004.

[19] HOWE, N. and W. STRAUSS, 2007. The next 20 years: how customer and workforce attitudes will evolve. Harvard Business Review, 85(07/08), 41-52.

[20] IPN - Podpora technických a přírodovědných oborů, 2011 - 2012. Baby Boomers. In: Generacey.cz [online]. (C) 2011 - 2012 [vid. 28. srpna 2018]. Dostupné z: https://www.generacey.cz/zjisti-jaka-jsi-generace.

[21] ISSA, T. and P. ISAIAS, 2016. Internet factors influencing generations $\mathrm{Y}$ and $\mathrm{Z}$ in Australia and Portugal: A practical study. Information Processing and Management, 52(01), 592-617. DOI: http://dx.doi.org/10.1016/j.ipm.2015.12.006.

[22] KLAPILOVÁ KRBOVÁ, P., 2016. Generation Y Attitudes towards Shopping: A Comparison of the Czech Republic and Slovakia. Journal of Competitiveness, 08(01), 38-54.

[23] KUMARI, N., 2012. A Study of the Recruitment and Selection process: SMC Global. Industrial Engineering Letters, 02(01), 34-44. ISSN 2224-6096.

[24] LEE, I., 2011. Modelling the benefit of e-recruiting process integration. Decision Support Systems, 51(01), 230-239. DOI: 10.1016/j.dss.2010.12.011.

[25] OFORI, D. and M. ARYEETEY, 2011. Recruitment and selection practices in small and medium enterprises. International Journal of Business Administration, 02(03), 45-60.

[26] OPATHA, H. H. D. N. P. (2016). Human resource management. 7th ed. Colombo. ISBN 978-955-95885-9-7.

[27] ROWE, M., 2008. Generation revelation. Restaurant hospitality, 01(01), 26-30.

[28] SKEELS, M. M. and J. GRUDIN, 2009. When social networks cross boundaries: a case study of workplace use of Facebook and LinkedIn. In Proceedings of the ACM 2009 International Conference on Supporting Group Work, 95-104. ISBN 978-1-60558500-0. DOI: 10.1145/1531674.1531689.

[29] URBANCOVÁ, H., K. STACHOVÁ and Z. STACHO, 2015. Methods of Recruitment in the Czech and Slovak Organizations. Acta Universitatis Agriculturae et Silviculturae Mendelianae Brunensis, 63(03), 1051-1060. DOI: https://doi.org/10.11118/actaun201563031051.

[30] WEST, M., 2014. What Manufacturers Need to Know About Generation Z. Manufacturing Engineering, 153(01), 168.

[31] WIEDMER, T., 2015. Generations do differ: best practices in leading traditionalists, boomers, and generations X, Y, and Z. Delta Kappa Gamma Bulletin, 82(01), 51-58.

[32] WUEST, B., S. WELKEY, J. MOGAB and K. NICOLS, 2008. Exploring consumer shopping preferences: three generations. Journal of Family and Consumer Science, 100(01), 31-37.

[33] YAN, J., 2003. Corporate responsibility and the brands of tomorrow. Journal of Brand Management, 10(01), 290-302.

[34] ZOTTOLI, M. A. and J. P. WANOUS, 2000. Recruitment source research: Current status and future directions. Human Resource Management Review, 10(04), 353-382. DOI: dx.doi.org/10.1016/S1053-4822(00)00032-2. 